\title{
Comparative Analysis of Physical and Biochemical Attributes of Edible Fig (Ficus carica L.) Collected from Three Districts of Azad Jammu and Kashmir Located at Different Elevations
}

\section{Muhammad Ahsan Naseer ${ }^{1}$, Mehdi Maqbool ${ }^{1}$, Saima Rafiq ${ }^{2 *}$, Noosheen Zahid $^{1}$,Abdul Hamid ${ }^{1}$ and Syed Zulfiqar Ali Shah ${ }^{1}$}

${ }^{1}$ Department of Horticulture, Faculty of Agriculture, University of the Poonch Rawalakot (UPR), Azad Jammu and Kashmir, Pakistan; 'Department of Food Science and Technology, Faculty of Agriculture, University of the Poonch Rawalakot (UPR), Azad Jammu and Kashmir, Pakistan.

Abstract | Elevation could play a significant role in defining the final quality of fresh fruits. In AJK, fig is grown successfully in hilly areas such as Rawalakot, where the topography of this area is not even as compared to plane areas of this region. Therefore, current study was designed to assess the outcome of elevations on physical and biochemical attributes of wild fig collected from different localities of three selected Districts [Bagh (Arja, Bagh city, Dholi), Poonch (Hajira, Dwarandi, Akhorbun) and Kotli (Sehnsa, Kotli city, Khoiratta)] of AJK. Samples of wild fig fruits were collected and analysed for physical (fruits weight, fruits diameter, neck length) and biochemical attributes ( $\mathrm{pH}$, titratable acidity, total soluble solids, total moisture, vitamin $\mathrm{C}$, total phenolic and antioxidant activity). Results showed that wild figs obtained from diverse localities have different attributes in terms of physical as well biochemical properties. Maximum fruits weight $(6.24 \mathrm{~g})$, fruits diameter $(24.09 \mathrm{~mm})$, and neck length $(9.51 \mathrm{~mm})$ was observed in fruits harvested from Arja location of Bagh District, while the minimum fruit weight $(2.48 \mathrm{~g})$, fruit diameter $(16.69 \mathrm{~mm})$, and neck length $(2.81 \mathrm{~mm})$ was observed in fruits harvested from Khoiratta location of District Kotli. Similarly, in terms of biochemical quality attributes, maximum titratable acidity $(0.30 \%)$, total soluble solids (14.02 oBrix), total moisture $(77.54 \%)$, vitamin C (9.29 mg/100g), total phenolic contents $(14.83 \%)$ and antioxidant activity (38.66 \%) was observed in fruits harvested from Arja location of Bagh District, while the minimum titratable acidity $(0.14 \%)$, total soluble solids (10.42 ${ }^{\circ}$ Brix), total moisture content $(67.67 \%)$, vitamin C (6.62 $\mathrm{mg} / 100 \mathrm{~g})$, total phenolics (5.93\%) and antioxidants (17.33\%) were found in figs harvested from Khoiratta locality of District Kotli. Based on the results obtained during study, it is suggested that District Bagh is more suitable for growing fig as compared to other two locations of Azad Jammu and Kashmir. However, detailed studies are needed to establish its supply chain system and storage conditions for its marketing at national and international level.

Received | November 01, 2019; Accepted | September 05, 2020; Published | October 05, 2020

*Correspondence | Saima Rafiq, Department of Food Science and Technology, Faculty of Agriculture, University of the Poonch Rawalakot (UPR), Azad Jammu and Kashmir, Pakistan; Email: saimaft2009@gmail.com

Citation | Naseer, M.A., M. Maqbool, S. Rafiq, N. Zahid, A. Hamid, S.Z.A. Shah. 2020. Comparative analysis of physical and biochemical attributes of edible fig (Ficus carica L.) collected from three districts of Azad Jammu and Kashmir located at different elevations. Pakistan Journal of Agricultural Research, 33(4): 707-713.

DOI | http://dx.doi.org/10.17582/journal.pjar/2020/33.4.707.713

Keywords | Physical characteristics, Biochemical characteristics, Edible fig, Elevations 
Introduction

$\mathrm{F}$ (Ficus carica L.) fruits are known by humans since early times. They are cultivated in tropical, subtropical and in moderate climatic conditions of temperate regions (Pio et al., 2019). Duenas et al. (2008) reported that figs are normally eaten fresh as the edible portion of fruit is plump, muffled and like a receptacle. Total area under fig cultivation is 125 hectares and production is 500 tonnes in Pakistan which is very low as compared to rest of the world which is about one million tonnes approximately (GOP, 2014).

A small portion of figs produced worldwide is dried under the sun while a little portion is utilized for jams and other products (Mars et al., 2008). Figs are very well recognized due to their nutritional value and are considered a good produce of important minerals, carbohydrates, vitamins and fibers. Figs are free from fats and cholesterols and also comprise of very high amount of amino acids (Solomon et al., 2006; Vebric et al., 2008a; Slatnar et al., 2011). Most of the species of fig contain high amount of phenolics, organic acids and volatiles (Kusano et al., 2002). Several compounds like phenolics, phytoterols, organic acids, anthocyanins. are present in fig fruits which contribute to the antioxidant properties and allied health promoting attributes.

Fruit composition and morphological characteristics are very much dependant on two main factors, genetics and environment (Soqanloo, 2015). It is reported in many studies that particular varieties are composed of certain chemical substances due to their genetic makeup which might vary from species to species (Nascimento et al., 2017). However, the effect of environment on morphological and quality traits has also been reported, which could play a critical role in defining the final quality attributes of any produce (Míguez Bernárdez et al., 2004).

In this regard, few studies have been conducted on different crops which could be referred to the fig production in hilly areas such as Rawalakot, where the topography of this area is not even as compared to plane areas of this region. In a recent study by Dinis et al. (2011) it was clearly observed that when $C$. sativa was grown at different elevations, smaller fruits were noticed at higher altitudes. Similar results were also reported by Soqanloo (2015), when biochemical characteristics (vitamin, sugars, antioxidants, acids) of persimmon fruits were significantly affected by different elevations.

Topographic variation, various altitude features and vegetative cover, has made the climate of Azad Jammu and Kashmir state a tremendous place for growing variety of fruits. There is a huge contrast in climatic conditions of this state as the amount of rain, snow and temperature vary from one place to another. Further, the wild edible fig grows on natural forests and marginal lands with minimum economic output. Therefore, there is an enormous need and scope to study the variation among wild edible fig species grown in this region.

Thus, the present study was designed to see a comparison of physico-chemical attributes of wild figs grown at three selected districts of AJK located at different elevations.

\section{Materials and Methods}

Fresh fruits of edible fig grown wildly were obtained from nine different areas of three selected districts of AJK. Selection of locations was done on the basis of different elevations. Temperature data for the selected locations was collected from Pakistan Meteorological Department, Azad Jammu and Kashmir. Temperature data included mean maximum temperature for the growing season of fig (Table 1 ). Fig fruits were sampled from three different trees from each location which were used as replicates. Freshly harvested figs were brought in cardboard boxes to the Lab of Horticulture Department for physical and biochemical analysis. Twenty uniformly mature fruits (dark purple stage) were used to measure different parameters related to physical and biochemical quality.

\section{Physical analysis}

Fruit weight (g): Weight of wild figs obtained from various locations was measured using digital balance and expressed in grams $(\mathrm{g})$.

Fruit diameter (mm): Diameter of wild figs obtained from various locations was measured using Vernier calliper.

Neck length (mm): Wild figs were collected from various locations to measure length of their neck using scale. 
Table 1: Different locations selected from three Districts of Azad Jammu and Kashmir based on elevations and mean maximum temperature for fig growing season.

\begin{tabular}{llllll} 
Locations & $\begin{array}{l}\text { Dis- } \\
\text { tricts }\end{array}$ & $\begin{array}{l}\text { Ele- } \\
\text { vation } \\
(\mathbf{f t})\end{array}$ & Latitude & $\begin{array}{l}\text { Longi- } \\
\text { tude }\end{array}$ & $\begin{array}{l}\text { Mean max. } \\
\text { tempera- } \\
\text { ture }\left({ }^{\circ} \mathrm{C}\right)\end{array}$ \\
Arja & Bagh & 3663 & $33.996^{\circ} \mathrm{N}$ & $73.726^{\circ} \mathrm{E}$ & $30^{\circ} \mathrm{C}$ \\
Bagh city & & 3405 & $33.973^{\circ} \mathrm{N}$ & $73.791^{\circ} \mathrm{E}$ & $31^{\circ} \mathrm{C}$ \\
Dholi & 3365 & $33.657^{\circ} \mathrm{N}$ & $73.798^{\circ} \mathrm{E}$ & $32^{\circ} \mathrm{C}$ \\
Hajira & Poonch & 3168 & $33.181^{\circ} \mathrm{N}$ & $73.735^{\circ} \mathrm{E}$ & $33^{\circ} \mathrm{C}$ \\
Dwarandi & 3201 & $33.224^{\circ} \mathrm{N}$ & $73.744^{\circ} \mathrm{E}$ & $32^{\circ} \mathrm{C}$ \\
Akhorbun & 3239 & $33.436^{\circ} \mathrm{N}$ & $73.716^{\circ} \mathrm{E}$ & $32^{\circ} \mathrm{C}$ \\
Sehnsa & Kotli & 2228 & $33.512^{\circ} \mathrm{N}$ & $73.755^{\circ} \mathrm{E}$ & $35^{\circ} \mathrm{C}$ \\
Kotli city & & 2168 & $33.536^{\circ} \mathrm{N}$ & $73.734^{\circ} \mathrm{E}$ & $36^{\circ} \mathrm{C}$ \\
Khoiratta & 2073 & $33.523^{\circ} \mathrm{N}$ & $73.776^{\circ} \mathrm{E}$ & $37^{\circ} \mathrm{C}$ \\
\hline
\end{tabular}

Temperature data source: Pakistan Meteorological Department, Azad Jammu and Kashmir.

\section{Biochemical analysis}

Titratable acidity (TA) (\%): TA in wild figs was measured by AOAC (2012) (No. 9720.21).

Total soluble solids (TSS) (oBrix): TSS was calculated using hand refractometer (Kyoto Company, Japan) at room temperature.

Total moisture content (\%): Total moisture content were calculated according to AOAC (2012) (No. 920.13).

Vitamin C (mg/100g): Vitamin C of wild figs was calculated by method of AOAC (2012) (No. 967.22). 2,6-dichlorophenol indophenol dye was utilized to measure vitamin $\mathrm{C}$.

Total phenolic content (\%): The amount of total phenolic content was calculated by method of Singleton et al.(1999) using UV-vis spectrophotometer (UV-4000 spectrophotometer Hamburg, Germany). A sample was prepared by using Folin-Ciocalteau's Reagent (10\%) (2.5 ml) and sodium carbonate solution (7.5\%) $(2 \mathrm{ml})$ mixed with extract $(0.5 \mathrm{ml})$. Incubation was done for $40 \mathrm{~min}$ at $45^{\circ} \mathrm{C}$ and absorbance was taken at $765 \mathrm{~nm}$. Total phenolic contents were calculated using formula as:

$$
\text { Total phenolic content }(\%)=\frac{1.13 \times \mathrm{A}_{765}}{\text { Weight of sample }} \times 100
$$

Antioxidant activity (\%)

Antioxidant activity of wild figs was taken using
DDPH method. 1.1 diphenyl 2 picryl hydrazy (DPPH) was used as free radical. A methanolic solution $(50 \mu \mathrm{l})$ from each diluted $(1: 6)$ extract was poured in experimental test tubes and $0.1 \mathrm{mM}$ methanolic solution $(200 \mu \mathrm{l})$ of DPPH was mixed with it and kept in dark at ambient temperature. A decrease in absorbance of DPPH at $517 \mathrm{~nm}$ was taken after 5 min interval till this absorbance was stable. DDPH radical scavenging activity of used extract was taken by using the formula given below.

$$
\text { DPPH scavenging activity }(\%)=A_{\circ}-A s / A_{\circ} \times 100
$$

\section{Statistical analysis}

To analyse samples collected randomly from various locations, a completely randomized design (CRD) was used with three replications and each replication consisted of twenty fruits. Data recorded was analysed using analysis of variance (ANOVA) technique and statistical software (Statistix 8.1) was used for measuring significance among locations and comparison of treatment means were done using Turkey's test at probability level of $P<0.05$.

\section{Table 2: Physical quality attributes of fig fruits collected from different locations of three Districts of Azad Jammu

\begin{tabular}{|c|c|c|c|c|}
\hline ions & Districts & $\begin{array}{l}\text { Fruit weight } \\
\text { (g) }\end{array}$ & $\begin{array}{l}\text { Fruit diame- } \\
\text { ter }(\mathrm{mm})\end{array}$ & $\begin{array}{l}\text { Neck length } \\
\text { (mm) }\end{array}$ \\
\hline Arja & \multirow[t]{3}{*}{ Bagh } & $6.24 \pm 0.12 \mathrm{a}$ & $24.09 \pm 2.34 \mathrm{a}$ & $9.51 \pm 1.02 \mathrm{a}$ \\
\hline Bagh city & & $5.50 \pm 0.09 \mathrm{a}$ & $23.17 \pm 2.16 \mathrm{a}$ & $9.32 \pm 0.09 \mathrm{a}$ \\
\hline Dholi & & $5.39 \pm 0.10 \mathrm{a}$ & $23.14 \pm 2.12 \mathrm{a}$ & $9.10 \pm 0.09 \mathrm{a}$ \\
\hline Hajira & \multirow[t]{3}{*}{ Poonch } & $5.24 \pm 0.08 \mathrm{~b}$ & $21.58 \pm 1.45 \mathrm{~b}$ & $7.00 \pm 0.08 \mathrm{~b}$ \\
\hline Dwarandi & & $5.31 \pm 0.09 \mathrm{~b}$ & $22.68 \pm 1.34 \mathrm{~b}$ & $6.81 \pm 0.07 b$ \\
\hline Akhorbun & & $5.35 \pm 0.08 \mathrm{~b}$ & $22.70 \pm 1.21 \mathrm{~b}$ & $5.50 \pm 0.06 b$ \\
\hline Sehnsa & \multirow[t]{4}{*}{ Kotli } & $3.55 \pm 0.04 c$ & $18.22 \pm 1.14 \mathrm{c}$ & $3.23 \pm 0.05 c$ \\
\hline Kotli city & & $3.18 \pm 0.04 \mathrm{c}$ & $17.70 \pm 1.12 \mathrm{c}$ & $2.96 \pm 0.06 \mathrm{c}$ \\
\hline Khoiratta & & $2.48 \pm 0.03 c$ & $16.69 \pm 1.09 \mathrm{c}$ & $2.81 \pm 0.05 c$ \\
\hline$P$ value & & $0.0063^{* *}$ & $0.0011^{* *}$ & $0.0000^{* *}$ \\
\hline
\end{tabular} and Kashmir.}

Means in each column with different letters are significantly different at $P<0.05$ according to Tukey's test. \pm represents the standard error of means for three replicates.

\section{Results and Discussion}

\section{Physical attributes}

Results regarding physical attributes of edible fig as influenced by different elevations of different Districts showed significant $(P<0.05)$ difference for all the parameters studied (Table 2). Fig fruits 
harvested from three different locations (Arja, Bagh city, Dholi) of District Bagh showed maximum fruit weight $(6.24 \mathrm{~g}, 5.50 \mathrm{~g}, 5.39 \mathrm{~g})$, respectively, which was followed by weight of fig fruits harvested from three different locations [Hajira (5.24 g), Dwarandi (5.31 g), Akhorbun (5.35 g)] of District Poonch. However, the minimum fruit weight of fig was observed in fruits harvested from three different locations [Sehnsa (3.55 g), Kotli city (3.18 g), Khoiratta (2.48 $\mathrm{g})]$ of District Kotli. Similar results were recorded for fruit diameter and neck length of wild figs harvested from nine locations of three different Districts. Where fig fruits harvested from three different locations (Arja, Bagh city, Dholi) of District Bagh showed maximum fruit diameter $(24.09 \mathrm{~mm}, 23.17$ $\mathrm{mm}, 23.14 \mathrm{~mm}$ ), respectively, which was followed by diameter of fig fruits harvested from three different locations [Hajira (21.58 mm), Dwarandi (22.68 $\mathrm{mm})$, Akhorbun $(22.70 \mathrm{~mm})]$ of District Poonch. However, the minimum fruit diameter of fig was observed in fruits harvested from three different locations [Sehnsa $(18.22 \mathrm{~mm})$, Kotli city (17.70 $\mathrm{mm})$, Khoiratta $(16.69 \mathrm{~mm})]$ of District Kotli. While in case of neck length fig fruits harvested from three different locations (Arja, Bagh city, Dholi) of District Bagh showed maximum neck length $(9.51 \mathrm{~mm}, 9.32$ $\mathrm{mm}, 9.10 \mathrm{~mm}$ ), respectively, which was followed by neck length of wild figs harvested from three selected locations [Hajira $(7.00 \mathrm{~mm})$, Dwarandi $(6.81 \mathrm{~mm})$, Akhorbun $(5.50 \mathrm{~mm})$ ] of District Poonch. However, the minimum neck length of wild figs was observed in fruits harvested from three selected locations [Sehnsa $(3.23 \mathrm{~mm})$, Kotli city $(2.96 \mathrm{~mm})$, Khoiratta $(2.81 \mathrm{~mm})]$ of District Kotli.

Table 3: Biochemical quality attributes of fig fruits collected from different locations of three Districts of Azad Jammu and Kashmir.

$\begin{array}{llllllll}\text { Locations } & \text { Districts } & \text { TA(\%) } & \text { TSS (*Brix) } & \begin{array}{l}\text { Total moisture } \\ \text { content (\%) }\end{array} & \begin{array}{l}\text { Vitamin C } \\ (\mathbf{m g} / \mathbf{1 0 0 g})\end{array} & \begin{array}{l}\text { Total phenolic } \\ \text { content (\%) }\end{array} & \begin{array}{l}\text { Antioxidant } \\ \text { activity (\%) }\end{array} \\ \text { Arja } & \text { Bagh } & 0.30 \pm 0.02 \mathrm{a} & 14.15 \pm 1.67 \mathrm{a} & 77.54 \pm 5.34 \mathrm{a} & 9.29 \pm 1.34 \mathrm{a} & 14.83 \pm 1.72 \mathrm{a} & 38.66 \pm 3.12 \mathrm{a} \\ \text { Bagh city } & & 0.24 \pm 0.02 \mathrm{ab} & 14.02 \pm 1.56 \mathrm{ab} & 76.68 \pm 5.23 \mathrm{ab} & 9.16 \pm 1.23 \mathrm{ab} & 13.13 \pm 1.12 \mathrm{~b} & 35.33 \pm 3.20 \mathrm{ab} \\ \text { Dholi } & & 0.24 \pm 0.02 \mathrm{ab} & 13.58 \pm 1.12 \mathrm{ab} & 75.97 \pm 5.22 \mathrm{abc} & 7.51 \pm 1.11 \mathrm{bc} & 12.20 \pm 1.10 \mathrm{c} & 31.00 \pm 2.34 \mathrm{bc} \\ \text { Hajira } & \text { Poonch } & 0.20 \pm 0.01 \mathrm{ab} & 12.75 \pm 1.20 \mathrm{ab} & 72.47 \pm 4.65 \mathrm{~cd} & 7.24 \pm 1.10 \mathrm{c} & 8.60 \pm 1.09 \mathrm{e} & 27.00 \pm 2.12 \mathrm{~cd} \\ \text { Dwarandi } & & 0.21 \pm 0.01 \mathrm{ab} & 13.05 \pm 1.09 \mathrm{ab} & 73.17 \pm 4.12 \mathrm{bc} & 7.33 \pm 1.10 \mathrm{c} & 7.86 \pm 1.09 \mathrm{e} & 25.33 \pm 2.31 \mathrm{cde} \\ \text { Akhorbun } & & 0.23 \pm 0.01 \mathrm{ab} & 12.96 \pm 1.07 \mathrm{ab} & 73.90 \pm 4.34 \mathrm{abc} & 7.38 \pm 1.10 \mathrm{c} & 10.23 \pm 1.10 \mathrm{~d} & 26.66 \pm 2.14 \mathrm{~cd} \\ \text { Sehnsa } & \text { Kotli } & 0.18 \pm 0.01 \mathrm{~b} & 12.22 \pm 1.02 \mathrm{ab} & 68.69 \pm 3.23 \mathrm{de} & 7.06 \pm 0.09 \mathrm{c} & 6.83 \pm 0.09 \mathrm{f} & 18.00 \pm 2.09 \mathrm{ef} \\ \text { Kotli city } & & 0.17 \pm 0.01 \mathrm{~b} & 11.33 \pm 1.00 \mathrm{ab} & 67.84 \pm 3.12 \mathrm{e} & 6.80 \pm 0.08 \mathrm{c} & 6.30 \pm 0.08 \mathrm{fg} & 23.00 \pm 2.06 \mathrm{def} \\ \text { Khoiratta } & & 0.14 \pm 0.01 \mathrm{~b} & 10.42 \pm 0.09 \mathrm{~b} & 67.67 \pm 3.20 \mathrm{e} & 6.62 \pm 0.06 \mathrm{c} & 5.93 \pm 0.07 \mathrm{~g} & 17.33 \pm 1.98 \mathrm{f} \\ P \text { value } & & 0.0020^{* *} & 0.0320^{*} & 0.0000^{* *} & 0.0002^{* *} & 0.0000^{* * *} & 0.0000^{* *}\end{array}$

Means in each column with different letters are significantly different at $P<0.05$ according to Tukey's test; TA: Titratable acidity; TSS: Total soluble solids; \pm represents the standard error of means for three replicates.

Table 4: Correlation analysis between temperature and physical and biochemical attributes of fig collected from different locations of three Districts of Azad Jammu and Kashmir.

\begin{tabular}{|c|c|c|c|c|c|c|c|c|c|}
\hline & $\begin{array}{l}\text { Fruit } \\
\text { weight }\end{array}$ & $\begin{array}{l}\text { Fruit } \\
\text { diameter }\end{array}$ & $\begin{array}{l}\text { Neck } \\
\text { length }\end{array}$ & TA & TSS & $\begin{array}{l}\text { Total mois- } \\
\text { ture content }\end{array}$ & $\begin{array}{l}\text { Vitamin } \\
\text { C }\end{array}$ & $\begin{array}{l}\text { Total phenol- } \\
\text { ic content }\end{array}$ & $\begin{array}{l}\text { Antioxidant } \\
\text { activity }\end{array}$ \\
\hline \multicolumn{10}{|l|}{ Fruit weight } \\
\hline Fruit diameter & 0.9885 & & & & & & & & \\
\hline Neck Length & 0.9090 & 0.9243 & & & & & & & \\
\hline TA & 0.9147 & 0.9061 & 0.8731 & & & & & & \\
\hline TSS & 0.9515 & 0.9471 & 0.9214 & 0.9263 & & & & & \\
\hline Total moisture content & 0.9452 & 0.9666 & 0.9679 & 0.9359 & 0.9489 & & & & \\
\hline Vitamin C & 0.7383 & 0.7332 & 0.8150 & 0.8590 & 0.8269 & 0.8407 & & & \\
\hline Total phenolic content & 0.8427 & 0.8563 & 0.9098 & 0.9475 & 0.8913 & 0.9514 & 0.9068 & & \\
\hline Antioxidant activity & 0.8676 & 0.8686 & 0.9270 & 0.9290 & 0.8834 & 0.9348 & 0.9073 & 0.9543 & \\
\hline Temperature & -0.9844 & -0.9847 & -0.9191 & -0.9434 & -0.9730 & -0.9687 & -0.8212 & -0.8897 & -0.8959 \\
\hline
\end{tabular}


It is clear from the observations made in this study that physical quality of fig fruits was influenced by the elevations tested. Table 1 indicates that with increase in 150-200 ft elevation, there is one degree decrease in temperature. Fruit weight, fruit diameter and neck length increased as the elevation increased. This variation in quality could be due to the variation in climatic conditions, environmental factors, availability and intensity of sunlight. Moreover, it could be due to the higher rate of transpiration associated with higher irradiance, which had affected the invasion of water and nutrients to the fruit. Similar outcomes were observed by Polat and Calişkan (2008) where fig fruits grown at higher elevations possessed more weight as compared to fruits grown at locations of lower altitudes. Murray et al. (2005) also reported that more fruit weight was recorded in plum fruits grown at higher elevations.

\section{Biochemical attributes}

Results regarding biochemical attributes of edible fig as influenced by different elevations of different Districts showed significant $(P<0.05)$ difference for all the parameters studied (Table 3). Wild figs harvested from selected locations of Districts Bagh and Poonch showed higher TA (\%) values, TSS (oBrix), total moisture content (\%), vitamin C $(\mathrm{mg} / 100 \mathrm{~g})$, total phenolics (\%) and antioxidants (\%) as compared to different selected locations of District Kotli.

Difference in TA, TSS, total moisture content, vitamin $\mathrm{C}$, total phenolics and antioxidants in fig fruits harvested from different locations of three Districts could be affected by change in climatic conditions including temperature, relative humidity, rainfall and altitude. As altitude increased the value of biochemical attributes also increased which is clear from correlation analysis (Table 4). Our findings are closely related to the findings of various scientists who have reported earlier in similar studies conducted on different fruits grown at different altitudes (Coronado et al., 2015; Arslan and Ozcan, 2011; Polat et al., 2010; Vebric et al., 2008b; Mousa et al., 1996).

Correlation analysis between physical and biochemical attributes of fig can be due to pleiotropic effect or genetic linkage, but previous studies showed that temperature can play an important role (Bashir et al., 2019). Table 4 showed that with decrease in temperature the fruit quality increased which might be due to different environmental factors. Thus, at this stage, the correlations we have reported should be taken as provisional, till multi-locational trials are performed and the results give a clear picture of either a contribution of environment or genetic makeup of plants.

\section{Conclusions and Recommendations}

It could be concluded from the present study that fig fruits grown at higher elevations showed better quality characteristics as compared to fruits grown at lower elevations. From all the nine different locations selected for this study, Arja location of District Bagh showed the most promising results in terms of both physical quality as well as biochemical quality which could be attributed to difference in temperature. While fig fruits grown at Khoiratta location of District Kotli showed the lowest quality attributes. However, further studies are required to learn about its supply chain system and storage conditions for its marketing at domestic as well as foreign level.

\section{Acknowledgment}

Authors acknowledge University of Poonch Rawalakot for financial support of the present study.

\section{Novelty Statement}

Topographic variation has a significant role in growth and quality of fresh fruits. Fig fruits grown at District Bagh gave the best results in terms of growth and quality which showed that District Bagh has ideal climatic conditions for fig production at commercial level.

\section{Author's Contribution}

M. Ahsan Naseer performed experiments in Lab. Mehdi Maqbool, Noosheen Zahid and Saima Rafiq helped in planning, execution and data interpretation. Mehdi Maqbool, Syed Zulfiqar Ali Shah and Abdul Hamid supervised and reviewed the experiment.

\section{Conflict of interest}

The authors have declared no conflict of interest.

\section{Ethical review}

It is to confirm here that there was no involvement of any humans or animals in this study. 
References

Abbasi, A.M., M.A. Khan and M. Zafar. 2013. Ethno-medicinal assessment of some selected wild edible fruits and vegetables of lesserHimalayas, Pakistan. Pak. J. Bot., 45: 215-222.

AOAC, 2012. Official method of analysis. The association of official analytical chemists. $14^{\text {th }}$ Edition. Arlington, VA.

Arslan, D. and M.M. Özcan. 2011. Phenolic profile and antioxidant activity of olive fruits of the Turkish variety "Sariulak" from different locations. Grasas. Aceites, 62(4): 453-461. https://doi.org/10.3989/gya.034311

Bashir, S., S.Z.A. Shah, R.M.M. Naz, A. Hamid, S. Anjum, N. Zahid, M. Maqbool, M.I. Khan, A. Yaqoob, Z.H. Khan and A. Afzal. 2019. Physicochemical evaluation of field pea (pisum sativum L.) landraces under rainfed conditions of AJ and K-Pakistan. Pure Appl. Biol., 8(2): 1033-1042. https://doi.org/10.19045/ bspab.2019.80044

Coronado, A.P., G. Fischer and J.H. CamachoTamayo. 2015. Development and quality of pineapple guava fruit in two locations with different altitudes in Cundinamarca, Colombia. Bragantia, 74(3): 359-366. https://doi. org/10.1590/1678-4499.0459

Dinis, L.T., F. Peixoto, T. Pinto, R. Costa, R.N. Bennett and J. Gomes-Laranjo. 2011. Study of morphological and phenological diversity in chestnut trees ('Judia' variety) as a function of temperature sum. Environ. Exp. Bot., 70: 110-120. https://doi.org/10.1016/j. envexpbot.2010.08.003

Dueñas, M., J.J. Pérez-Alonso, C. Santos-Buelga and T. Escribano-Bailón. 2008. Anthocyanin composition in fig (Ficus carica L.). J. Food Comp. Anal., 21(2): 107-115. https://doi. org/10.1016/j.jfca.2007.09.002

GoP, 2014. Ministry of national food security and research. Fruit, Vegetables and Condiments Statistics of Pakistan. pp. 1-2.

Kusano, G., S. Orihara, D. Tsukamoto, M. Shibano, M. Coskun, A. Guvenc and C.S. Erdurak. 2002. Five new nortropane alkaloids and six new amino acids from the fruit of Morus alba LINNE growing in Turkey. Chem. Pharm. Bull., 50(2): 185-192. https://doi.org/10.1248/ cpb. 50.185

Mars, M., K. Chatti, O. Saddoud, A. Salhi-
Hannachi, M. Trifi and Marrakchi M. 2008.

Fig cultivation and genetic resources in Tunisia, an overview. Acta Hortic., 798: 27-32. https:// doi.org/10.17660/ActaHortic.2008.798.2

Míguez Bernárdez, M., J. De la Montańa Miguelez and J. García Queijeiro. 2004. HPLC determination of sugars in varieties of chestnut fruits from Galicia (Spain). J. Food Compos. Anal., 17: 63-67. https://doi.org/10.1016/ S0889-1575(03)00093-0

Mousa, Y. M., D. Gerasopoulos, I. Metzidakis and A. Kiritsakis. 1996. Effect of altitude on fruit and oil quality characteristics of 'Mastoides' olives. J. Sci. Food Agric., 71 (3): 345-350. https://doi.org/10.1002/ (SICI)1097-0010(199607)71:3<345::AIDJSFA590>3.0.CO;2-T

Murray, X.J., D.M. Holcroft, N.C. Cook and S.J.E. Wand. 2005. Postharvest quality of 'Laetitia' and 'Songold' (Prunus salicina Lindell) plums as affected by preharvest shading treatments. Postharvest Biol.Technol., 37(1):81-92.https:// doi.org/10.1016/j.postharvbio.2005.02.014

Nascimento, L.M., L.G.C. Garcia, T. Ogata, D.C. Brandão, C.M. Silva-Neto and A. Seleguini. 2017. Physical and chemical characteristics and productivity of persimmons (Diospyros kaki L.) cultivated in the Brazilian savannah. Aust. J. Crop Sci., 11: 234-240. https://doi. org/10.21475/ajcs.17.11.02.p247

Pio, R., F.B. M. de Souza, L. Kalcsits, R.B. Bisi and D.H. da Farias. 2019. Advances in the production of temperate fruits in the tropics. Acta Sci. Agron., 41: e39549. https://doi. org/10.4025/actasciagron.v41i1.39549

Polat,A.A andO.Çalişkan.2008.Fruitcharacteristics of table fig (Ficus carica) cultivars in subtropical climate conditions of the Mediterranean region. N.Z.J. Crops Hortic. Sci., 36: 107-115. https:// doi.org/10.1080/01140670809510226

Polat, A.A., O. Caliskan, S. Serce, O. Saracoglu, C. Kaya and M. Ozgen. 2010. Determining total phenolic content and total antioxidant capacity of loquat cultivars grown in Hatay. Pharmacogn. Mag., 6(21): 5-8. https://doi. org/10.4103/0973-1296.59959

Singleton, V.L., R. Orthofer and R.M. LamuelaRaventós. 1999. Analysis of total phenols and other oxidation substrates and antioxidants by means of folin-ciocalteu reagent. Methods Enzymol., 299: 152-178. https://doi. 
org/10.1016/S0076-6879(99)99017-1

Slatnar, A., U. Klancar, F. Stampar, and R. Veberic. 2011. Effect of drying of figs (Ficus carica L.) on the contents of sugars, organic acids, and phenolic compounds. J. Agric. Food Chem., 59(21): 11696-11702. https://doi.org/10.1021/ jf202707y

Solomon, A., S. Golubowicz, Z. Yablowicz, S. Grossman, M. Bergman, H.E. Gottlieb, A. Altman, Z. Kerem and M.A. Flaishman. 2006. Antioxidant activities and anthocyanin content of fresh fruits of common fig (Ficus carica L.). J. Agric. Food Chem., 54(20): 7717-7723. https:// doi.org/10.1021/jf060497h
Soqanloo, S.S., 2015. Effect of different regional climates on persimmon quality. J. Civil Eng. Environ. Sci., 1: 8-12. https://doi. org/10.17352/2455-488X.000003

Veberic, R., J. Jakopič and F. Stampar. 2008a. Internal fruit quality of figs (Ficus carica L.) in the Northern Mediterranean region. Italian J. Food Sci., 20(2): 255-262.

Veberic, R., M.C. Bajc and F. Stampar. 2008b. Phenolic acids and flavonoids of fig fruit (Ficus carica L.) in the Northern Mediterranean region. Food Chem., 106(1): 153-157. https:// doi.org/10.1016/j.foodchem.2007.05.061 